\title{
ERCP practice beyond the training period - bridging the gap between guidelines and real-life practice: a single operator experience of 679 procedures
}

\author{
THEODOR VOIOSU ${ }^{1,2}$, ANDREI VOIOSU $^{1}$, ANDREEA BENGUŞ ${ }^{1}$, BOGDAN MATEESCU $^{1,2}$ \\ ${ }^{1}$ Gastroenterology Division, "Colentina" Clinical Hospital, Bucharest, Romania

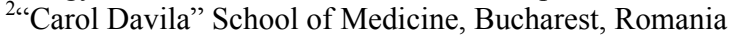

\begin{abstract}
Background. Endoscopic retrograde cholangiopancreatography has evolved significantly in recent years. The increase in complexity and range of applications has not been adequately reflected in an improvement of training methods for ERCP, with many endoscopists failing to meet required performance standards during their training period and limited available data on their performance immediately after completing training. We aimed to analyze the performance of an independent operator from a developing country after the completion of formal training with regard to procedure and patient-related outcomes.

Methods. We conducted an observational study of ERCPs performed by a young endoscopist from a referral center. Data about the procedure, cannulation technique (including use of precut), trainee involvement and procedure-related outcomes was retrieved and analyzed from a prospectively maintained database on quality in ERCP (the QUASIE initiative).

Results. Data from 679 consecutive ERCPs conducted or supervised by one endoscopist with $<200$ independent procedures prior to the study period were included in the final analysis. Cannulation rates significantly improved over time, from $90 \%$ to $96 \%(\mathrm{p}=0.016)$. Use of precut techniques changed significantly over time, with an initial increase followed by a subsequent decrease as overall cannulation rates improved. Trainee involvement was significantly associated with prolonged cannulation times $(p=0.003)$ and use of precut $(p=0.001)$, but did not impact on technical success or patient safety.

Conclusions. Independent practice of ERCP after the training period is characterized by ongoing changes in technique, especially with regard to cannulation and use of precut, showing significant improvements in performance over time.
\end{abstract}

Key words: ERCP; training; sphincterotomy; adverse events.

\section{INTRODUCTION AND STUDY AIMS}

Training standards in endoscopic retrograde cholangiopancreatography (ERCP) have been the focus of an on-going debate about the optimal number of procedures necessary for a trainee to achieve competency and for an established practitioner to maintain and further develop acquired skills $[1,2]$. This debate stems mainly from the concern that insufficient training and low case volumes for endoscopists might adversely affect procedure and patient outcome, resulting in higher rates of technical failure and procedure-related adverse events $[3,4]$. Based on data emerging mainly from academic tertiary referral centers, practice guidelines of national societies in most developed countries have been setting the bar ever higher, requiring trainees to complete a minimum of 180-200 ERCPs and achieve selective cannulation rates of $>85 \%$ before credentialing [5]. However, large audit studies of real life practice in the UK [6] and, more recently, the US [7] have shown that a majority of trainees do not achieve these goals during their training period. Developing countries are likely to fare even worse compared to these quality standards [8] although, barring some recent encouraging reports from China [9] and Libya [10], there is still insufficient data to describe the practice of ERCP on a large scale in these regions.

Furthermore, although selective cannulation of the common bile duct has been widely adopted as a surrogate marker of competency and has been extensively analyzed and validated in studies of ERCP training $[11,12]$, we currently lack the means to correctly describe the development of individual endoscopists beyond the minimum requirements of their basic training.

Our aim was to analyze the relationship between key quality indicators in ERCP (i.e. selective cannulation rate of the CBD, use and success of precut techniques, procedure-related adverse events rates) and the accrued case volume of an independent operator from a developing country after completing the mandatory training period. 


\section{MATERIALS AND METHODS}

\section{Study design}

We conducted a retrospective analysis of prospectively collected data for consecutive ERCPs conducted by a single independent operator (TV) with a previous experience of $<200$ procedures after completing the mandatory training in ERCP.

Patient-related data (age, gender, diagnosis, bilirubin levels) and procedure-related data (cannulation technique, difficulty level according to the Schutz scale [13], participation and degree of involvement of endoscopic trainees, procedurerelated adverse events) have been prospectively collected in the endoscopist's unit since January 2014 as part of two consecutive observational studies assessing risk factors for technical failure or procedure-related adverse events (QUASIE 1 and QUASIE 2 [14]).

All endoscopists participating in this project were required to report on technical aspects and procedure outcome using a standard report form. There were only minimal differences between study periods with regard to the collected data because of protocol amendments and updates, however data on some technical aspects was not available for analysis for the entire study period.

Inclusion criteria. All ERCPs performed by $\mathrm{TV}$, either as single operator or as supervisor for an advanced endoscopic trainee, with the intent of deep biliary cannulation and subsequent diagnostic or therapeutic procedures in the bile duct were included in the analysis.

Exclusion criteria. Cases where the papilla was not reached because of altered anatomy or strictures as well as cases with an indication for pancreatic duct therapy were excluded from the analysis.

\section{Endoscopist background}

Romanian curricula for training in endoscopy specifies that, during their 5 years of residency, trainees are required to assist in at least 30 ERCPs, with hands-on involvement at the discretion of their supervisor [15]. After their residency, advanced endoscopy trainees are expected to complete an additional 6 months of hands-on training, during which they are required to complete 50 ERCPs as individual operators before being allowed to practice independently [16]. Of note, at the end of these 6 months, credentialing is granted for all types of advanced therapeutic techniques, including EMR, EUS and ERCP after a theoretical examination.
During his training, the operator (TV) participated as operator and assistant in roughly 100 ERCPs and completed a 3 month observership in a high volume referral center for ERCP (Policlinico Agostino Gemelli, Rome, Italy). After completing the formal training, but before entering this study, TV performed an additional 70 procedure as singleoperator, taking the total caseload prior to study inception to around 170 ERCPs.

\section{ERCP protocol}

In our institution the standard cannulation technique for the whole duration of the study was the wire-guided technique using a standard triplelumen sphincterotome preloaded with a 0.035 inch hydrophilic guidewire. Minimal contrast injection is sometimes used to define distal bile duct anatomy, at the discretion of the main operator; for the purpose of this study all cases where selective cannulations directly followed a successful injection of the CBD were classified as contrast-guided cannulations. As a general rule cannulation using this technique is attempted for up to 10 minutes by either trainee or supervisor before other techniques such as double guide-wire or precutting techniques are applied. However, in case of repeated inadvertent injections or accessing of the Wirsung duct with the guidewire or in case of trauma to the papillary region, earlier attempts at adjunctive methods of cannulation were allowed, also at the discretion of the endoscopist. The preferred precut technique is needle-knife papillotomy, however in a minority of cases precut septotomy was also employed. ERCP procedures were usually carried out under propofol sedation, except for selected cases where general anesthesia was recommended by the attending anesthesiologist.

\section{Main outcome variables}

We selected deep cannulation of the common bile duct, use of precut technique and procedurerelated adverse events (defined using consensus guidelines [17] [2]) as the main outcome variables of our study in order to assess the performance of the endoscopist in relationship to accumulating experience during the study period. These represent important quality measures for ERCP and can be used as surrogate markers of endoscopist skill and performance over time. The procedures performed by TV after his training period were divided into consecutive blocks of 100 to allow the analysis and comparison of the outcome variables over time. 


\section{Data management and statistical analysis}

All the ERCPs from the QUASIE database were reviewed and all procedures performed by TV either as a single operator or as a supervisor for an endoscopic trainee, regardless of whether the trainee required hands-on assistance during the procedure, were included in the final database. Data were recorded and analyzed with SPSS for Windows, Version 16.0 (SPSS Inc., Chicago, Illinois, USA). Results were reported as mean and standard deviation for variables with a normal distribution, and as median, minimum, and maximum for variables with a non-normal distribution. Univariable analysis was conducted with the chi-squared test for nominal variables, with nonparametric tests (Mann - Whitney U test, Kruskall - Wallis test) for variables with a non-normal distribution, and with Student's t test for variables with a normal distribution. Multivariable analysis by logistic regression was used to better characterize the risk factors for the main outcome variables (cannulation of the CBD, use of precut and procedure-related adverse events). For the purpose of this regression, nominal variables with multiple categories were transformed into dichotomous variables possible to facilitate the interpretation of results. Two-sided hypothesis testing was used, with a $P$ value of less than 0.05 considered statistically significant.

\section{RESULTS}

Six hundred seventy-nine ERCP procedures (of which 502 (74\%) native papilla cases) conducted between January 2014 and December 2017 in the Gastroenterology Division at "Colentina" Clinical Hospital, Bucharest, by a single endoscopist (TV) were included in the final analysis. 380 procedures were performed by $\mathrm{TV}$ as a single operator $(56 \%)$, while in an additional 299 a trainee performed at least an attempt to cannulate the CBD under TV's supervision.

The main indication for ERCP was common bile duct stones (49.7\%), followed by malignant strictures $(33.2 \%)$ and stent exchange for various other indications $(5.7 \%) .51 .9 \%$ of patients were male and the mean age was $66.3( \pm 13.7)$ years.

\section{Cannulation of the CBD}

Deep cannulation of the bile duct was successful in $638(93.9 \%)$ of the 679 cases (Table 1). Wire-guided cannulation was achieved in $71.4 \%$ of the cases, followed by precut technique (15.7\%) and contrast-guided cannulation (4.5\%) (Table 2).

There was a statistically significant difference in cannulation rates over time, which improved from around $90 \%$ in the first 300 cases to over $96 \%$ for the subsequent cases $(\mathrm{p}=0.016$ Pearson's Chi Square) and this was also observed when analysis was restricted to native papilla cases only $(\mathrm{p}=$ 0.046 Pearson's ChiSquare). On multivariable analysis the only risk factors for failed cannulation after adjusting for patient age, gender and bilirubin levels and trainee involvement were endoscopist caseload (OR 0.995 CI 95\% 0.993-0.998 for each additional procedure performed) and any other diagnosis beside common bile duct stones (OR 6.9, CI 95\% 2.5-18.9).

For the procedures where time to cannulation was available there was also a statistically significant increase in the percentage of procedures where deep biliary cannulation was achieved in 5 minutes or less, from around $50 \%$ in the first 500 procedures to $70 \%$ for the following cases (Table 3, $\mathrm{p}=0.01, \mathrm{r}=-0.1$, Kendall Tau-b correlation).

\section{Use of precut techniques}

Precut rates were initially low for the first 200 procedures $(<5 \%)$, with a steep increase up to $27 \%$ over the following 200 procedures, followed by a slow but steady decrease over the next period, ultimately reaching a precut rate of $12 \%$ by the end of the study period (Fig. 1).

On multivariate analysis, after adjusting for the rank of the procedure (caseload number), patient age, gender and bilirubin levels, the only 2 risk factors for the use of precutting techniques were a diagnosis other than CBD stones (OR 2.2, 95\%CI 1.3-3.7) and procedures involving a trainee (OR 2.6, 95\% CI 1.6-4.5).

\section{Procedure-related adverse events}

There were 74 procedures where at least 1 procedure-related adverse event was reported on follow-up (11\%). The rates of AE varied from a minimum of $7 \%$ to a maximum of $14.1 \%$ along the study period, but this difference was not statistically significant $(p=0.52)$. Most adverse events were classified as either mild or moderate, but there were 6 cases of severe AE and 5 deaths reported for the entire study period, accounting for a postprocedural mortality rate of $0.7 \%$ at 30 days follow-up.

PEP was the most frequent procedure-related adverse event with a total of 33 cases (4.9\%), with 
rates ranging between 2 to $10 \%$ over the study period, but this difference was also not statistically significant $(p=0.6)$. There were no statistically significant differences over time for the other documented $\mathrm{AE}$ (cholangitis, perforation and bleeding) (Table 1).

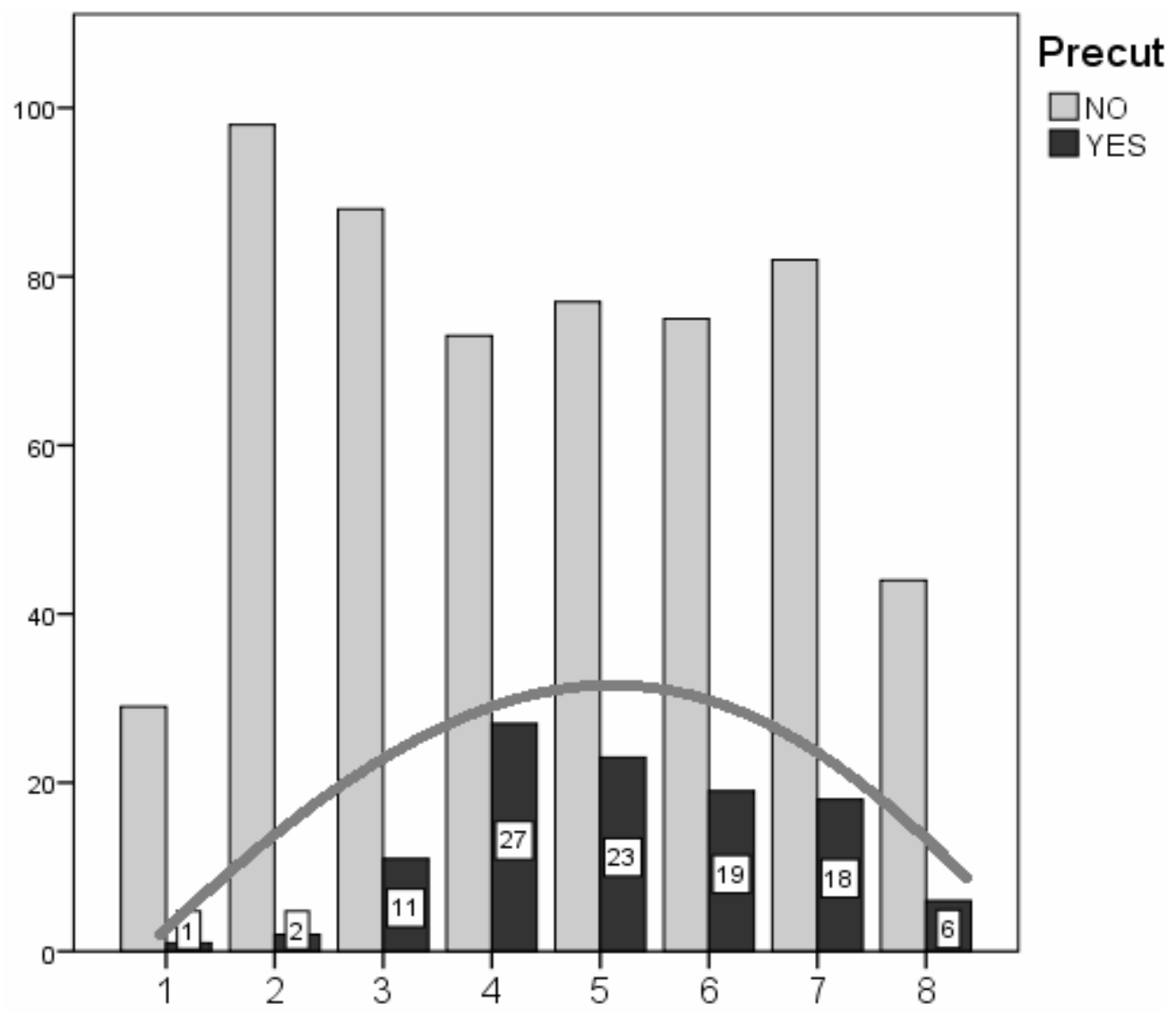

Figure 1. Changes in the use of precutting techniques over time (caseload is divided into subgroups of 100 procedures).

On multivariate analysis, after adjusting for the rank of the procedure, patient age, gender, bilirubin levels, diagnosis and trainee involvement the only risk factor for procedure-related adverse event was the use of precut technique (OR 4.2,
95\%CI 1.6-10.7) (Table 4). Use of precut was also the only risk factor for developing PEP (OR 4.7, 95\% CI 1.1-20) on multivariable analysis, but it was not a statistically significant risk factor for bleeding or perforation.

Table 1

Evolution of the main procedure-related quality measures over time

\begin{tabular}{|c|c|c|c|c|c|c|c|c|c|}
\hline Caseload (range) & $70-100$ & $101-200$ & 201-300 & $301-400$ & $401-500$ & $501-600$ & $601-700$ & $701-750$ & $\mathbf{p}$ \\
\hline $\begin{array}{l}\text { Overall deep biliary } \\
\text { cannulation rates }(\%)\end{array}$ & $90 \%$ & $90 \%$ & $89 \%$ & $93 \%$ & $97 \%$ & $93.6 \%$ & $99 \%$ & $100 \%$ & $0.016 *$ \\
\hline $\begin{array}{l}\text { Cannulation rates in native } \\
\text { papilla cases }(\%)\end{array}$ & $90.9 \%$ & $86.8 \%$ & $87.1 \%$ & $92.2 \%$ & $95.8 \%$ & $92.3 \%$ & $98.4 \%$ & $100 \%$ & $0.046^{*}$ \\
\hline Use of precut technique (\%) & $3.3 \%$ & $2 \%$ & $11 \%$ & $27 \%$ & $23 \%$ & $20.2 \%$ & $18 \%$ & $12 \%$ & $<0.001 *$ \\
\hline Any adverse event (\%) & $13.3 \%$ & $14 \%$ & $9.2 \%$ & $14.1 \%$ & $7 \%$ & $7 \%$ & $13.1 \%$ & $12 \%$ & 0.52 \\
\hline PEP (\%) & $6.7 \%$ & $9 \%$ & $4.1 \%$ & $7.1 \%$ & $1 \%$ & $3 \%$ & $2 \%$ & $10 \%$ & 0.06 \\
\hline Bleeding (\%) & $0 \%$ & $2 \%$ & $1 \%$ & $1 \%$ & $1 \%$ & $2 \%$ & $0 \%$ & $0 \%$ & 0.81 \\
\hline Cholangitis (\%) & $6.6 \%$ & $4 \%$ & $4 \%$ & $4 \%$ & $4 \%$ & $0 \%$ & $8 \%$ & $0 \%$ & 0.12 \\
\hline Perforation (\%) & $0 \%$ & $0 \%$ & $0 \%$ & $1 \%$ & $0 \%$ & $0 \%$ & $1 \%$ & $1 \%$ & 0.57 \\
\hline $\begin{array}{l}\text { Procedures as supervisor } \\
\text { (\%) }\end{array}$ & $0 \%$ & $0 \%$ & $30 \%$ & $67 \%$ & $64 \%$ & $67 \%$ & $50 \%$ & $42 \%$ & $<0.001^{*}$ \\
\hline Crossover procedures (\%) & $\mathrm{N} / \mathrm{A}$ & N/A & $70 \%$ & $58 \%$ & $41.5 \%$ & $50 \%$ & $39.6 \%$ & $17.8 \%$ & $<0.001 *$ \\
\hline Grade $2 / 3$ difficulty (\%) & $20 \%$ & $22 \%$ & N/A & $\mathrm{N} / \mathrm{A}$ & N/A & $17 \%$ & $25 \%$ & $20 \%$ & 0.11 \\
\hline
\end{tabular}

*statistically significant using the ChiSquare test 
Table 2

Cannulation techniques used to access the CBD

\begin{tabular}{ll}
\hline Cannulation technique & Number (\%) \\
Wire-guided cannulation & $486(71.4 \%)$ \\
Contrast-guided cannulation & $31(4.5 \%)$ \\
Double guidewire technique & $6(0.9 \%)$ \\
Precut technique & $107(15.7 \%)$ \\
Other & $8(1.2 \%)$ \\
Failed cannulation & $41(6.1 \%)$ \\
\hline
\end{tabular}

Table 3

Evolution of the cannulation times during the study period. There was a statistically significant decrease in cannulation times with increased caseload $(r=-0.1, p=0.01$ Kendall tau-b)

\begin{tabular}{lccccc}
\hline Time to cannulation & $\mathbf{3 0 1 - 4 0 0}$ & $\mathbf{4 0 1 - 5 0 0}$ & $\mathbf{5 0 1 - 6 0 0}$ & $\mathbf{6 0 1 - 7 0 0}$ & $\mathbf{7 0 1 - 7 5 0}$ \\
$<\mathbf{5}$ mins $(\%)$ & 44 & 56 & 51 & 70 & 70 \\
$\mathbf{5 - 1 0}$ mins $(\%)$ & 18 & 19 & 17 & 15 & 12 \\
$>\mathbf{1 0}$ mins $(\%)$ & 31 & 23 & 21 & 13 & 18 \\
\hline
\end{tabular}

Table 4

Multivariate analysis of risk factors for any procedure-related adverse event

\begin{tabular}{lll}
\hline Variable & OR & $\mathbf{9 5 \% C I}$ \\
Procedure rank (ID) & 1 & $0.999-1.001$ \\
Gender & 0.97 & $0.585-1.627$ \\
Age & 1.003 & $0.984-1.022$ \\
Bilirubin levels & 1.006 & $0.973-1.039$ \\
CBD stones $(\boldsymbol{y} / \boldsymbol{n})$ & 1.471 & $0.820-2.640$ \\
Role (single operator/supervisor) & 1.798 & $0.658-4.912$ \\
No precut use & $\mathbf{0 . 2 3 8}$ & $\mathbf{0 . 0 9 3 - 0 . 6 0 6}$ \\
\hline
\end{tabular}

\section{Impact of trainee participation on procedure outcome}

There were no procedures involving trainees in the first 170 documented cases, leading to a total caseload of just below 250 ERCPs performed as a single operator by TV prior to the first case where he acted as a supervisor for an advanced endoscopic trainee. A total of 299 procedures (44\%) of the procedures included in this study had variable degrees of trainee involvement categorized as failed attempts at cannulation (101/299), successful deep biliary cannulation by trainee with various degrees of hands on assistance from the supervisor still required (47/299) and only verbal instructions required for the completion of the entire procedure by the trainee (141/299).

Cannulation times were significantly longer in procedures with trainee participation (Table 5), but overall cannulation rates of the CBD in native papilla cases were not significantly different in cases where TV acted as a supervisor compared to those where no trainee was involved, over a similar period of time $(93.4 \%$ vs. $91.8 \%, \mathrm{p}=0.6 \mathrm{Chi}-$ Square).

Also, precut rates were significantly higher in native papilla cases involving a trainee $(30.5 \%$ $70 / 229)$ compared to those where no trainee was involved $(13.7 \%, 37 / 269)(\mathrm{p}<0.001)$.

Table 5

Time to cannulation according to trainee involvement

\begin{tabular}{lcccc}
\hline & $<$ minutes & $\mathbf{5 - 1 0}$ minutes & $>$ 10 minutes & $\mathbf{p}$ \\
No trainee involved & 86 & 19 & 31 & $\mathbf{0 . 0 0 3} *$ \\
Trainee involved & 98 & 57 & 61 & \\
\hline
\end{tabular}

*statistically significant using the Pearson's ChiSquare

\section{DISCUSSION}

To our knowledge, this is one of the largest and most in-depth studies to report on the changes in technique and outcome of ERCP as a result of accumulating experience for a young endoscopist in a developing country.

In our study, we employ several key quality measures such as selective cannulation of the CBD, cannulation method (including precut rates) and 
procedure-related adverse events to analyze the evolution of ERCP performance over time for an inexperienced endoscopist from a developing country.

The main novel finding of our study is related to the particular relationship between the rate of selective cannulation of the CBD and use of precut techniques over time. While selective cannulation rates continuously improve over the study period, precut rates follow a bell-shaped curve, increasing steeply in the first study period and then slowly decreasing. This increase in cannulation rates and decreasing need for precut towards the end of the study period is paralleled by a significant decrease in the time required for successful cannulation of the CBD. These observations are consistent with the idea that endoscopists need to use precutting techniques less and less as they gain experience in ERCP and their cannulation technique improves [18].

Trainee involvement in the procedure might also contribute to the high variation of rates of precut use reported in real life practice, ranging between 5 and $31 \%$ after some reports [19]. Our study has shown that trainee involvement was associated with a significant increase in the use of precut by the supervisor. This might reflect the inexperience of the endoscopist acting as a supervisor, the need for expedient access to the CBD advocated by some supporters of early precut $[20,21]$ or both.

Since the seminal study by Verma et al. [22], most studies focusing on the learning curves of young endoscopists practicing ERCP have evaluated the cannulation rates of the CBD as a surrogate marker of proficiency $[11,22,23]$. Despite the large number of cases included in some of these studies, only seldom is any trainee followed for a meaningful period of time and procedures, with most studies averaging around 100 procedures per trainee [12]. Furthermore, the very optimistic results from the study of Verma, showing a steep learning curve for deep biliary cannulation associated with a very low postERCP complication rate $(<2 \%$ PEP and no perforations) were, most likely, the reflection of training in an elite unit, under exceptional mentorship and have not been replicated in subsequent studies. Paradoxically, however, this study seems to have almost single-handedly set the standard for most recent guidelines recommendations in ERCP training [24].

Our study is similar in design to the study of Verma, following the performance of a single operator over a long period, with in-depth data on cannulation technique and procedure outcome. The main difference in results comes from the significantly higher rates of precut observed in our cohort and the relationship between trainee involvement and additional increase in precut rates. We believe that this difference reflects the two very distinct backgrounds for the single operators whose caseloads were analyzed - one practicing ERCP in an elite referral unit from a developed country and the other practicing ERCP in a developing country, with limited access to mentorship for advanced endoscopic procedures. In Romania there is a recognized unmet need for endoscopic training, especially in the field of advanced endoscopic techniques such as ERCP, with a national survey from 2006 reporting less than 3000 ERCPs performed nationwide during the whole year of which less than 200 involved trainees [25]. By comparison, the national benchmarking program from 2006 estimated that around 15.000 ERCP procedures were performed yearly in Austria, a country with less than half the population of Romania.

The main limitation of our study is the fact that it reflects the performance of a single endoscopist and, as such, the results might not apply to a different operator or a different endoscopy unit. Our findings are consistent with results from an earlier study from our training programme [26] which suggested that trainee involvement leads to delayed access to the CBD and a more frequent use of precut, without compromising procedure outcome, and also with results from a British study showing that trainee involvement delays access to the CBD [27]. Because of the relative paucity of data in the field of ERCP training and the inherent limitations of our study, our results must necessarily be interpreted with caution. We hypothesize that increased use of precut might be a result of several contributing factors - local factors particular to developing countries (i.e. - limited caseloads and experience for both trainees and mentors leading to inherent deficiencies in the training programmes) as well as the trend favoring early precut to avoid the complications associated with prolonged cannulation attempts. It is important to underscore the fact that procedure-related outcomes from our cohort, both in terms of technical success and procedure-related adverse events, compared favorably with suggested quality standards, with a cannulation rate consistently above $85 \%$ and low-complication rates, even when trainees were involved. Also, the limited data available from studies of endoscopic practice just 
after the training period suggests that precut rates for endoscopists starting independent practice is above $10 \%$, without compromising technical success and patient safety $[28,29]$.

Our study also suggests that we might need to look beyond the limited time-frame of advanced endoscopic training in order to understand the factors that shape an endoscopist's skill set, particularly when cannulation technique, including the use of precut, are concerned and also the timing and degree of involvement in the education of other endoscopists training in ERCP. As our results have shown, there are significant variations in the performance of ERCP with relation to both accrued experience and the role of supervisor, extending over a long period of time ( $>500$ procedures).

Furthermore, because it is currently difficult to envision a long-term, in-depth, multicenter study aimed at describing intraprocedural parameters such as cannulation technique including adequate caseloads for individual endoscopists coming from developing countries, we believe that studies such as our own may constitute an adequate basis for further inquiries into this important subject matter.

Additional studies are required to analyze and validate our preliminary data, but we believe that it is time to move in the direction advocated by Peter Cotton [30] and extend the scope of research into the field of ERCP training and development, so as to include much needed data on the performance and outcome of ERCP from real life settings, including the "outer regions" of academic endoscopy.

Conflict of interest: None to declare.

Acknowledgement. The first author would like to thank Prof. Guido Costamagna and Prof. Vincenzo Perri and doctors Andrea Tringali, Pietro Familiari and Ivo Boskoski from the Endoscopy Unit at Policlinico Gemelli, Rome, for their guidance and help during his advanced endoscopy training period.

Introducere. Colangiopancreatografia retrogradă endoscopică a evoluat semnificativ in ultimele decade. Complexitatea crescută şi spectrul de aplicații practice $n u$ au fost însă reflectate corespunzător în metodele de pregătire ale endoscopiş̧ilor, aceştia reuşind rareori să întrunească standardele minime de performanță impuse pe durata pregătirii. De asemenea, există puține date care să reflecte performanțele acestor endoscopişti imediat după terminarea stagiilor de pregătire. Scopul acestui studiu a fost să analizeze rezultatele tehnice ale unui operator independent în ERCP, în perioada imediat următoare încheierii pregătirii formale in ERCP.

Material şi metode. Am efectuat o analiză retrospectivă a unor date colectate prospectiv privind performanțele tehnice ale unui singur operator dintr-un centru terțiar. Datele despre procedură, tehnica de canulare a căii biliare (inclusiv utilizarea tehnicilor de presecționare), eventuala implicare a unui endoscopist in curs de pregătire precum şi rezultatul procedurii (inclusiv efectele adverse) au fost extrase dintr-o bază de date prospectivă (studiul QUASIE).

Rezultate. Date despre 679 ERCPuri consecutive efectuate sau supervizate de un singur endoscopist cu experiență redusă (sub 200 proceduri inainte de inițierea studiului) au fost incluse în analiza finală. Rata de canulare a crescut semnificativ in timp, de la $90 \%$ la $96 \%(p=0.016)$. Utilizarea tehnicilor de presecționare s-a modificat semnificativ în timp, cu o creştere inițială urmată de o scădere a ratei de presecționare, pe măsură ce rata de canulare global a crescut. Implicarea unui endoscopist începător s-a asociat cu o creştere semnificativă a timpului de canulare $(p=0.003)$, cu o utilizare crescută a tehnicilor de presecționare $(p=0.001)$, dar nu a influențat siguranța pacientului sau succesul procedurii.

Concluzii. Practicarea independentă a ERCPului după perioada de pregătire se caracterizează printr-o ameliorare continuă în timp a tehnicii operatorului, în special în ceea ce priveşte canularea selectivă şi tehnica de presecționare.

Correspondence to: Theodor Voiosu, M.D, Ph.D, Gastroenterology Department, "Colentina” Clinical Hospital,

19-21 Stefan cel Mare Boulevard, Bucharest, Romania

E-mail: theodor.voiosu@gmail.com 


\section{REFERENCES}

1. SHAHIDI N, OU G, TELFORD J, ENNS R. When trainees reach competency in performing ERCP: a systematic review. Gastrointest Endosc. 2015;81(6):1337-42. doi: 10.1016/j.gie.2014.12.054. Epub 2015 Apr 1.

2. COTTON PB. Are low-volume ERCPists a problem in the United States? A plea to examine and improve ERCP practiceNOW.Gastrointest Endosc. 2011;74(1):161-6. doi: 10.1016/j.gie.2011.03.1233.

3. SIIKI A, TAMMINEN A, TOMMINEN T, KUUSANMÄKI P. ERCP procedures in a Finnish community hospital: a retrospective analysis of 1207 cases. Scand J Surg. 2012;101(1):45-50.

4. KAPRAL C, DULLER C,WEWALKA F et al. Case volume and outcome of endoscopic retrograde cholangiopancreatography: results of a nationwide Austrian benchmarking project. Endoscopy 2008; 40: 625-630

5. ASGE STANDARDS OF PRACTICE COMMITTEE, FAULX AL, LIGHTDALE JR, ACOSTA RD et al. Guidelines for privileging, credentialing, and proctoring to perform GI endoscopy.Gastrointest Endosc. 2017;85(2):273-281. doi: 10.1016/ j.gie.2016.10.036.

6. WILLIAMS EJ, TAYLOR S, FAIRCLOUGH P et al. Are we meeting the standards set for endoscopy? Results of a large-scale prospective survey of endoscopic retrograde cholangio-pancreatograph practice. Gut. 2007;56(6):821-9. Epub 2006 Dec 4.

7. COTE GA, KESWANI RN, JACKSON T et al. Individual and practice differences among physicians who perform ERCP at varying frequency: a national survey. Gastrointest Endosc 2011;74:65-73.

8. TALUKDAR R, NAGESHWAR REDDY D. ERCP in developing countries: the way forward. Gastrointest Endosc. 2016;84(4):667-9. doi: 10.1016/j.gie.2016.04.037.

9. HU LH, XIN L, LIAO Z, et al. ERCP development in the largest developing country: a national survey from China in 2013. Gastrointest Endosc 2016;84:659-66.

10. TUMI A, MAGADMI M, ELFAGEIH S et al. ERCP in a cohort of 759 cases: A 6-year experience of a single tertiary centre in Libya. J Gastroenterol. 2015;16(1):25-8.

11. EKKELENKAMP VE, KOCH AD, RAUWS EA, BORSBOOM GJ, DE MAN RA, KUIPERS EJ. Competence development in ERCP: the learning curve of novice trainees. Endoscopy. 2014;46(11):949-55.

12. SHAHIDI N, OU G, TELFORD J, ENNS R. When trainees reach competency in performing ERCP: a systematic review. Gastrointest Endosc. 2015;81(6):1337-42.

13. SCHUTZ SM, ABBOTT RM. Grading ERCPs by degree of difficulty: A new concept to produce more meaningful outcome data. Gastrointest Endosc 2000; 51: 535-539.

14. VOIOSU T, BENGUS A, VOIOSU A et al. Trainee caseload correlates with ERCP success rates but not with procedurerelated complications: results from a prospective study (the QUASIE cohort). Endosc Int Open. 2016;4(4):E409-14.

15. https://rezidentiat.ms.ro/curricule/2017/gastroenterologie_2017.pdf, accessed on 13.02.2018.

16. http://www.emedic.ro/Examene/Publicatie-de-examen-pentru-obtinerea-atestatelor-de-studii-complementare-pentru-medici-medicidentisti-si-farmacisti.htm, accessed on 12.02.2018.

17. COTTON PB, LEHMAN G, VENNES J et al. Endoscopic sphincterotomy complications and their management: an attempt at consensus. Gastrointest Endosc 1997; 37: 383-393

18. HAREWOOD GC, BARON TH. An assessment of the learning curve for precut biliary sphincterotomy. Am J Gastroenterol 2002; 97: 1708-1712.

19. TESTONI PA, MARIANI A, AABAKKEN L et al. Papillary cannulation and sphincterotomy techniques at ERCP: European Society of Gastrointestinal Endoscopy (ESGE) Clinical Guideline.Endoscopy. 2016;48(7):657-83.

20. LOPES L, DINIS-RIBEIRO M, ROLANDA C. Early precut fistulotomy for biliary access: time to change the paradigm of "the later, the better"?. Gastrointest Endosc. 2014;80(4):634-41.

21. NAVANEETHAN U, KONJETI R, VENKATESH PG, et al. Early precut sphincterotomy and the risk of endoscopic retrograde cholangiopancreatography related complications: An updated meta-analysis. World J Gastrointest Endosc 2014; 6: 200-208.

22. VERMA D, GOSTOUT CJ, PETERSEN BT et al. Establishing a true assessment of endoscopic competence in ERCP during training and beyond: a single-operator learning curve for deep biliary cannulation in patients with native papillary anatomy. Gastrointest Endosc. 2007;65(3):394-400.

23. VITALE GC, ZAVALETA CM, VITALE DS, et al. Training surgeons in endoscopic retrograde cholangiopancreatography. Surg Endosc 2006;20: 149-52.

24. MOON HS, CHOI EK, SEO JH et al. Education and Training Guidelines for the Board of the Korean Society of Gastrointestinal Endoscopy. Clin Endosc. 2017;50(4):345-356.

25. BATAGA S, TANTAU M, CRISTIAN G et al. ERCP in Romania in 2006; a National Programme seems mandatory. J Gastrointestin Liver Dis 2007; 16(4):431-5.

26. VOIOSU T, VOIOSU A, BENGUS A et al. Trainee involvement increases precut rates and delays access to the common bile duct without an increase in procedure-related adverse events: a brave new world of ERCP training? Rom J Intern Med.2018;56:55-61.

27. FROST JW, KURUP A, SHETTY S, FISHER N. Does the presence of a trainee compromise success of biliary cannulation at ERCP? Endosc Int Open 2017; 5(7):E559-E562.

28. RIESCO-LÓPEZ JM, VÁZQUEZ-ROMERO M, RIZO-PASCUAL JM et al. Efficacy and safety of ERCP in a low-volume hospital.Rev Esp Enferm Dig. 2013;105(2):68-73.

29. NALANKILLI K, KANNUTHURAI S, MOSS A. A modern approach to ERCP: maintaining efficacy while optimising safety. Dig Endosc. 2016;28 Suppl 1:70-6.

30. COTTON PB. It's not the precut; it's the why done and who by. Gastrointest Endosc. 2010;72(5):1114; author reply 1114. doi: 10.1016/j.gie.2010.02.028.

Received November 3, 2018 